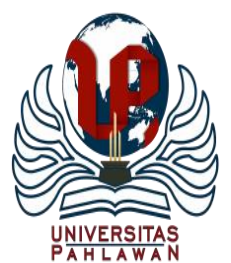

Edukatif : Jurnal Ilmu Pendidikan Volume 3 Nomor 4 Tahun 2021 Halm 1437 - 1445

EDUKATIF: JURNAL ILMU PENDIDIKAN

Research \& Learning in Education

https://edukatif.org/index.php/edukatif/index

\title{
Upaya Guru PAI Dalam Meningkatkan Kemampuan Kognitif Siswa Pada Mata Pelajaran Fiqih Di Masa Pandemi Covid-19
}

\author{
Nujumul Laily ${ }^{凶}$ \\ Universitas Ibn Khaldun Bogor \\ E-mail : nujumulaily@gmail.com
}

\begin{abstract}
Abstrak
Adanya wabah Covid-19 menjadikan pembelajaran dilaksanakan secara daring, hal ini dapat mempengaruhi kemampuan kognitif siswa. Namun guru yang berkompetensi dapat mengembangkan dan meningkatkan kemampuan kognitif siswa dalam kondisi apapun, hal ini perlu dilakukan karena dengan kemampuan kognitif tersebut dapat memudahkan siswa dalam belajar. Maka dari itu perlu adanya upaya dari guru PAI untuk meningkatkan kemampuan kognitif siswa di masa pandemi ini. Penelitian ini bertujuan untuk mengetahui bagaimana upaya guru PAI dalam meningkatkan kemampuan kognitif siswa pada mata pelajaran fiqih di masa pandemi Covid-19 dan untuk mengetahui faktor apa saja yang mempengaruhi kemampuan kognitif siswa. Metode yang digunakan pada penelitian ini yaitu metode kualitatif. Adapun pendekatan yang digunakan pada penelitian ini adalah pendekatan deskriptif kualitatif. Untuk mendapatkan data, teknik yang dipakai yaitu wawancara, observasi, dan dokumentasi. Data yang sudah terkumpul dianalisis dengan melalui empat cara, yaitu meliputi: pengumpulan data, reduksi data, penyajian data, dan penarikan kesimpulan. Hasil penelitian menunjukkan bahwa upaya guru PAI dalam meningkatkan kemampuan kognitif siswa pada mata pelajaran fiqih di masa pandemi Covid-19 yaitu: 1) menggunakan media pembelajaran 2) menggunakan metode pembelajaran 3) memberikan pengetahuan, pemahaman sehingga siswa dapat mengaplikasikan materi pelajaran 4) memberikan punishment yang mendidik 5) mengatasi kemampuan kognitif siswa yang rendah 6) mengadakan evaluasi pembelajaran.
\end{abstract}

Kata Kunci: Upaya Guru, Kemampuan Kognitif, Fiqih

\begin{abstract}
The Covid-19 outbreak makes learning online, which can affect students' cognitive abilities. But competent teachers can develop and improve students' cognitive abilities under any circumstances, this needs to be done because these cognitive abilities can facilitate students in learning. Therefore, there need to be efforts from PAI teachers to improve students' cognitive abilities during this pandemic. This study aims to find out how PAI teachers' efforts in improving students' cognitive abilities in fiqh subjects during the Covid-19 pandemic and to find out what factors affect students' cognitive abilities. The method used in this study is qualitative. The approach used in this study is a qualitative descriptive approach. To obtain data, the techniques used are interviews, observations, and documentation. The collected data is analyzed in four ways, including data collection, data reduction, data presentation, and conclusion drawing. The results showed that PAI teachers' efforts in improving students' cognitive abilities in fiqh subjects during the Covid-19 pandemic are: 1) using learning media 2) using learning methods 3) providing knowledge, understanding so that students can apply lesson material 4) provide punishment that educates 5) overcome low cognitive abilities 6) conduct learning evaluations.
\end{abstract}

Keywords: Teacher Efforts, Cognitive Ability, Fiqh

Copyright (c) 2021 Nujumul Laily

$\triangle$ Corresponding author:

Email : nujumulaily@gmail.com

DOI : https://doi.org/10.31004/edukatif.v3i4.596

ISSN 2656-8063 (Media Cetak)

ISSN 2656-8071 (Media Online)

Edukatif : Jurnal Ilmu Pendidikan Vol 3 No 4 Tahun 2021 p-ISSN 2656-8063 e-ISSN 2656-8071 
1438 Upaya Guru PAI Dalam Meningkatkan Kemampuan Kognitif Siswa Pada Mata Pelajaran Fiqih Di Masa Pandemi Covid-19 - Nujumul Laily

DOI: https://doi.org/10.31004/edukatif.v3i4.596

\section{PENDAHULUAN}

Kemunculan wabah Virus Corona Disease 2019 menjadikan Kementerian Pendidikan dan Kebudayaan (Kemendikbud) membuat peraturan baru. Sebagaimana peraturan tersebut ditulis dalam Surat Edaran (SE) No. 04 Tahun 2020 tentang Pelaksanaan Kebijakan Pendidikan dalam Covid-19. Satu di antara poin kebijakan tersebut adalah melaksanakan proses pembelajaran dari rumah melalui pembelajaran daring (dalam jaringan) guna memutus tali rantai penyebaran Covid-19 (Kebudayaan \& Indonesia, 2020). Untuk itu lembaga pendidikan dituntut untuk merubah sistem pembelajaran yang sudah ditetapkan sebelumnya seperti kurikulum, silabus, rencana pelaksanaan pembelajaran, penilaian dan evaluasi pembelajaran agar sesuai dengan perintah Kemendikbud. Pembelajaran daring ialah kegiatan belajar mengajar yang pada dasarnya dilakukan secara tidak langsung atau secara virtual melalui internet dengan memanfaatkan aplikasi yang bisa digunakan guru untuk menyampaikan materi pembelajaran kepada siswa (Syarifudin, 2020). Dalam penelitian yang dilakukan oleh Oktafia Ika Handarin dan Siti Sri Wulandari ditemukan bahwa pembelajaran daring dapat menjadikan siswa menjadi individu yang mandiri sebab menekankan pada student contered siswa juga menjadi lebih berani dalam menyampaikan pendapat atau ide-idenya (Handarini \& Wulandari, 2020).

Dalam kegiatan belajar mengajar perlu adanya keterkaitan antara guru dan siswa, maka dari itu guru memiliki peran penting dalam lembaga pendidikan, sebab guru memberikan ilmu yang ia punya dan siswa menerima ilmu tersebut, keduanya sama-sama berada di jalan yang mulia yaitu menuntut ilmu. Guru merupakan pendidik professional yang memiliki tugas utama untuk membimbing, mengarahkan, mengajar, menilai, mendidik, melatih, juga mengevaluasi siswa pada jenjang pendidikan sekolah dasar, serta pendidikan sekolah menengah baik SMP, SMA/SMK melalui pembelajaran formal (Surya, 2013). Baik buruknya guru dalam mengajar dan mendidik akan berpengaruh dan berdampak besar terhadap sikap dan kualitas pendidikan siswa. Oleh sebab itu guru harus memberikan contoh dan pengaruh positif kepada siswa dan lembaga pendidikan.

Guru juga memegang tugas untuk mengembangkan kognitif (cara berpikir) siswa, karena dengan kognitifnya itu dapat memudahkan siswa dalam pembelajaran. Kemampuan kognitif merupakan kemampuan seseorang dalam berfikir sehingga melibatkan pengetahuan, pemecahan masalah, penalaran, menilai, menghubungkan serta mempertimbangkan suatu peristiwa atau kejadian yang melibatkan akal atau bersifat rasional. (Rozana, 2020). Kemampuan kognitif perlu ditingkatkan dalam pendidikan agar dapat melahirkan kualitas lulusan sekolah yang baik, karena dalam peraturan pemerintah tentang "Standar Kompetensi Lulusan adalah kualifikasi kemampuan lulusan yang mencakup sikap, pengetahuan dan keterampilan" (Indonesia, 2006).

Dalam penelitian yang dilakukan oleh Prasetio Rumondor dan Nailil Maslukiyah ditemui bahwa terdapat siswa yang kemampuan kognitifnya tinggi sehingga mudah dalam memahami apa yang disampaikan guru dan juga terdapat siswa yang memiliki kemampuan kognitif yang lemah sehingga lambat dalam memahami apa yang guru sampaikan. Diketahui siswa dari lulusan SD memiliki kemampuan kognitif yang lemah dalam membaca al-Qur'an serta mempelajari tajwid dan siswa yang lulusan MIN rata-rata sudah bisa dan terbiasa dalam membaca al-Qur'an dan mempelajari tajwid serta mempraktekannya (Rumondor \& Nailil, 2019). Pada saat peneliti melakukan penelitian di MTs Negeri 3 Bogor ditemukan juga fakta bahwa kemampuan kognitif siswa berbeda-beda dalam mempelajari pelajaran fiqih, ada siswa yang kemampuan kognitifnya tinggi dan juga ada siswa yang kemampuan kognitifnya rendah, terutama selama pembelajaran daring ditemukan juga bahwa pengetahuan dan pemahaman siswa di MTs Negeri 3 Bogor pada mata pelajaran fiqih ada yang tinggi dan rendah, hal ini kembali kepada masing-masing individu karena selama pembelajaran daring guru hanya memberikan materi tugas melalui whatsapp selebihnya siswa mempelajari sendiri. Berdasarkan observasi yang dilakukan, kemampuan kognitif siswa yang tinggi salah satunya dipengaruhi oleh latar belakang pendidikan siswa sebelumnya dan salah satu penyebab kemampuan kognitif siswa rendah pada 
1439 Upaya Guru PAI Dalam Meningkatkan Kemampuan Kognitif Siswa Pada Mata Pelajaran Fiqih Di Masa Pandemi Covid-19 - Nujumul Laily

DOI: https://doi.org/10.31004/edukatif.v3i4.596

saat pembelajaran daring disebabkan oleh beberapa hal, seperti: waktu pembelajaran yang singkat, karena waktu pembelajaran daring pada mata pelajaran fiqih hanya dilaksanakan selama satu jam. Kurang nya penjelasan dari guru, karena pada mata pelajaran fiqih siswa harus betul-betul memahami isi materi di dalamnya sehingga siswa dapat mengaplikasikannya dalam kehidupan sehari-hari dan terkendala dari segi sinyal dan kuota, karena wilayah tempat tinggal siswa tidak semuanya berada pada jangkauan sinyal yang bagus.

Salah satu pihak yang dapat mengatasi hal tersebut adalah guru. Guru memiliki kompetensi pada dirinya sehingga dapat mengatasi permasalahan-permasalahan yang dialami pada saat proses belajar. Berdasarkan hasil penelitian terdahulu yang dilakukan oleh Prasetio Rumondor dan Nailil Maslukiyah bahwa untuk meningkatkan kompetensi kognitif siswa harus dilakukan beberapa upaya, upaya guru PAI dalam meningkatkan kompetensi kognitif yaitu dengan mengarahkan siswa untuk belajar di perpustakaan, kelompok belajar, menasehati siswa dan berinisiatif membuat forum belajar. Kemudian dalam proses pembelajaran guru memakai strategi ekspotisori yaitu dengan menggunakan metode ceramah, diskusi dan tanya jawab. Selain itu guru di MTs Negeri 1 Bongkuda juga melakukan evaluasi kepada siswa dengan cara pre-test dan memberikan pertanyaan setiap kali selesai pelajaran. (Rumondor \& Nailil, 2019). Ada perbedaan pada penelitian saat ini dengan penelitian terdahulu yang dilakukan Prasetio Rumondor dan Nailil Maslukiyah. Penelitian ini lebih dikhususkan pada masa pandemi dimana proses pembelajarannya dilakukan secara daring. Penelitian terdahulu membahas tentang bagaimana upaya guru PAI dalam meningkatkan kompetensi kognitif dan kepribadian siswa dan faktor pendukung dan penghambat guru PAI dalam meningkatkan kompetensi kognitif dan kepribadian Siswa di MTs Negeri 1 Bongkudai. Sedangkan penelitian ini membahas tentang bagaimana upaya guru PAI dalam meningkatkan kemampuan kognitif siswa pada mata pelajaran fiqih dimasa pandemi Covid-19 dan faktor yang mempengaruhi kemampuan kognitif siswa. Waktu dan tempat penelitiannya juga berbeda begitupun hasil temuan yang di dapat berbeda dengan penelitian ini.

Dari permasalahan diatas maka peneliti tertarik untuk mengetahui beberapa hal, diantaranya: Bagaimana upaya yang dilakukan guru PAI dalam meningkatkan kemampuan kognitif siswa pada mata pelajaran fiqih di masa pandemi Covid-19 dan Faktor apa saja yang mempengaruhi kemampuan kognitif siswa pada mata pelajaran fiqih di masa pandemi Covid-19. Tujuan dari penelitian ini yaitu untuk mengetahui upaya guru PAI dalam meningkatkan kemampuan kognitif siswa pada mata pelajaran fiqih di masa pandemi Covid19 dan untuk mengetahui faktor yang mempengaruhi kemampuan kognitif siswa pada mata pelajaran fiqih di masa pandemi Covid-19. Manfaat dari penelitian ini adalah kemampuan kognitif siswa MTs Negeri 3 Bogor dapat meningkat setelah guru melakukan beberapa upaya diatas.

\section{METODE PENELITIAN}

Rancangan penelitian yang digunakan pada penelitian ini adalah penelitian kualitatif dengan pendekatan deskriptif kualitatif. Deskriptif kualitatif ialah suatu gambaran atau deskripsi dari data yang telah ditemui di lapangan yang berkenaan dengan fakta yang akurat yang sedang diteliti. Kehadiran peneliti menjadi point utama dalam melakukan penelitian karena peneliti menyajikan dan mengumpulkan data dalam bentuk deskripsi. Subjek pada penelitian ini berjumlah 6 orang. Yaitu 2 orang guru PAI di MTs Negeri 3 Bogor, 3 orang siswa dan 1 orang kepala sekolah MTs Negeri 3 Bogor sebagai informan penelitian.

Adapun metode dalam pengumpulan data yaitu dengan melakukan Observasi, Studi dokumentasi dan Wawancara. Observasi dilakukan dengan mengamati keadaan sekolah MTs Negeri 3 Bogor sekaligus melakukan pengamatan terhadap proses pembelajaran daring dengan mencatat point-point pada lembar observasi. Studi dokumentasi dalam penelitian ini yaitu mengumpulkan data-data yang sudah ada di pihak sekolah untuk melengkapi data/informasi yang kurang pada penelitian ini. Wawancara dilakukan kepada guru fiqih secara mendalam yaitu dengan melakukan wawancara tidak struktur, peneliti mewawancarai guru fiqih terkait upaya yang dilakukan guru PAI dalam meningkatkan kemampuan kognitif siswa di masa pandemi 
1440 Upaya Guru PAI Dalam Meningkatkan Kemampuan Kognitif Siswa Pada Mata Pelajaran Fiqih Di Masa Pandemi Covid-19 - Nujumul Laily

DOI: https://doi.org/10.31004/edukatif.v3i4.596

Covid-19 dan terkait faktor apa saja yang mempengaruhi kemampuan kognitif siswa, selain kepada guru PAI peneliti juga melakukan wawancara kepada siswa dan kepala sekolah untuk memperkuat hasil jawaban dari guru PAI.

Penelitian ini dilakukan di sekolah MTsN 3 Bogor yang beralamat di Jl. Karadenan No.21B, Karadenan, Cibinong, Bogor, Jawa Barat. Waktu penelitian dilakukan selama 3 bulan yaitu pada bulan Januari-Maret 2021. Data yang di dapat kemudian dilakukan triangulasi sumber. Triangulasi sumber yaitu mencari atau memperoleh informasi dari berbagai sumber yang berbeda dengan memakai teknik yang sama (Pritandhari, 2017). Proses analisis data dilakukan dengan melalui empat tahap, diantaranya: pengumpulan data, reduksi data, penyajian atau display data dan kesimpulan atau verifikasi.

\section{HASIL DAN PEMBAHASAN PENELITIAN}

\section{Upaya Guru PAI dalam Meningkatkan Kemampuan Kognitif Siswa Pada Mata Pelajaran Fiqih di Masa Pandemi Covid-19}

Upaya adalah suatu usaha seseorang untuk menggapai sesuatu yang diinginkan. Begitupun guru PAI yang berupaya untuk mendidik, mengajarkan dan membimbing siswa dengan cara memberikan pengetahuan dan pemahaman ilmu agama agar mereka mengetahui dan memahami ilmu tersebut. Dalam kondisi pandemi saat ini, sebagian besar lembaga pendidikan melaksanakan pembelajaran secara daring dan pelaksanaan pembelajaran pun berubah total yang awalnya dilaksanakan secara langsung, untuk saat ini pembelajaran dilaksanakan melalui jaringan internet agar dapat mengurangi penyebaran Covid-19.

Maka dari itu setiap guru berupaya untuk tetap melaksanakan pembelajaran dan berupaya untuk dapat meningkatkan kemampuan kognitif siswa terutama di masa pandemi Covid-19 ini. Adapun hasil penelitian yang dilakukan melalui observasi, dokumentasi dan wawancara dengan guru PAI, siswa dan kepala sekolah peneliti menemukan beberapa upaya yang dilakukan guru PAI di MTsN 3 Bogor dalam meningkatkan kemampuan kognitif siswa pada mata pelajaran fiqih di masa pandemi Covid-19 adalah sebagai berikut:

a. Menggunakan Media Pembelajaran

Media pembelajaran dianggap hal penting dan mendukung untuk kondisi saat ini. Setiap guru di MTs Negeri 3 Bogor menggunakan media yang berbeda, awalnya pembelajaran dilakukan dengan menggunakan aplikasi $e$-learning yang dianjurkan oleh pemerintah, namun karena ada beberapa kesulitan dan kendala maka beberapa guru PAI memutuskan untuk menggunakan media yang mudah digunakan oleh guru dan siswa, yaitu Whatsapp Group. Pembelajaran dilakukan dengan menggunakan aplikasi whatsapp dinilai lebih simpel karena guru dapat mengirimkan materi pembelajaran yang akan dibahas dalam bentuk gambar, video, audio, doc, dan ppt. Group whatsapp dipilih sebagai salah satu media pembelajaran, sebab dilihat dari jumlah pengguna, cara penggunaan dan fungsinya yang mana guru dapat menyampaikan materi pelajaran ataupun berbagi tugas dalam bentuk gambar, video, audio, doc, ppt serta meminta tanggapan atau (jawaban) dari siswa (Pustikayasa, 2019).

Proses pembelajaran dengan menggunakan group whatsapp dapat dikatakan efektif karena siswa dan guru PAI sudah terbiasa menggunakan aplikasi tersebut dalam kehidupan sehari-hari sehingga tidak terjadi kesulitan dalam penggunaanya dan dalam waktu yang bersamaan guru PAI dapat memberikan informasi, tugas dan materi yang akan disampaikan kepada masing-masing kelas. Guru dan siswa sudah mengunakan media whatsapp dalam melakukan pembelajaran, hal tersebut juga terlihat ketika pembelajaran daring dilaksanakan menggunakan whatsapp group, guru dan siswa terlihat tidak mengalami kesulitan dalam melakukannya. Hal ini di dukung oleh penelitian Teguh Prasetyo dan Zulela M.S bahwa di sekolah MI Sirojul Athfal Kota Bogor melakukan pembelajaran daring menggunakan aplikasi Whatsapp dikarenakan aplikasi whatsapp mudah untuk digunakan (Prasetyo \& Zulela, 2021). Namun hal ini bertentangan dengan penelitian Mirzon Daheri, dkk bahwa menggunakan aplikasi Whatsapp sebagai media pembelajaran daring kurang efektif untuk mencapai tujuan pembelajaran disebabkan penjelasan guru yang sederhana dan kurangnya 
1441 Upaya Guru PAI Dalam Meningkatkan Kemampuan Kognitif Siswa Pada Mata Pelajaran Fiqih Di Masa Pandemi Covid-19 - Nujumul Laily

DOI: https://doi.org/10.31004/edukatif.v3i4.596

penjelasan yang komprehensif dari guru, rendahnya aspek psikomotorik dan afektif siswa pada pembelajaran, kesibukan orang tua, sinyal internet, serta latar belakang pendidikan orang tua yang berbeda-beda (Daheri et al., 2020).

\section{b. Menggunakan Metode Pembelajaran}

Dalam menggunakan metode pembelajaran pada pembelajaran daring diserahkan kepada masingmasing guru, oleh karena itu guru PAI MTs Negeri 3 Bogor memilih untuk menggunakan metode penugasan karena metode ini dapat dikatakan metode yang tepat untuk saat ini. Metode penugasan dilakukan agar siswa dapat memahami materi pelajaran, yaitu dengan cara menugaskan siswa untuk merangkum materi di buku catatan atau pun menggaris bawahi materi yang penting sekali untuk di fahami sehingga siswa dapat mencerna materi yang sekiranya penting untuk dipelajari dan difahami untuk mengasah kemampuan siswa dalam hal pemahaman, pengetahuan (kognitif) dan meminta siswa untuk mengisi soal di buku LKS/paket. Dengan menggunakan metode penugasan dapat menggali daya pikir siswa terkait materi yang dibahas oleh gurunya. Beberapa penugasan yang diberikan guru PAI kepada siswa yaitu siswa diminta untuk mengerjakan tugas sesuai materi pelajaran fiqih dan mencari sumber-sumber yang ada di buku, google dan youtube sesuai dengan pembelajaran hari itu. Contohnya seperti mencari gambar gerakan wudhu, sholat, dan lain-lain. Sesekali guru menghimbau kepada siswa untuk mempraktekan materi yang bisa dipraktekan, satu diantaranya adalah wudhu karena wudhu merupakan hal yang sangat penting dilakukan sebelum kita melaksanakan sholat. Hal ini sesuai dengan hasil penelitian Marsanda Claudia Parameswara dan Dinie Anggraeni Dewi bahwa pembelajaran yang dilakukan secara daring dengan menggunakan metode latihan dan penugasan dapat dikatakan sangat efektif. Dengan menggunakan metode latihan dan penugasan dalam pembelajaran daring juga bisa menumbuhkan kemandirian siswa (Parameswara \& Dewi, 2021)

Berdasarkan hasil observasi, terlihat dalam pembelajaran daring ketika guru dan siswa MTs Negeri 3 Bogor melakukan pembelajaran melalui whatsapp, guru memulai mata pelajaran fiqih dengan judul materi tentang makanan dan minuman yang halal dan haram. Diawal pembelajaran guru tersebut mengucapkan salam, mendoakan siswa/siswi dan tidak lupa memberikan motivasi pada siswa. Motivasi yang diberikan berupa dukungan dan semangat agar siswa/siswi selalu bersemangat dalam belajar. Setelah itu guru memberikan tugas kepada siswa untuk membuka LKS halaman 40, dan meminta siswa untuk mempelajari, membaca dan memahami tentang makanan dan minuman yang halal dan haram sampai hal 43 , kemudian siswa/siswi diminta untuk menggaris bawahi materi yang pentingnya saja. Selain itu siswa diminta untuk mencatat 2 ayat al-Qur'an yang menjelaskan tentang perintah kepada umat Muslim untuk memakan makanan yang halal, kemudian hasil dari tugas tersebut difoto dan dikirim melalui whatsapp.

Pemberian tugas ini dapat dijadikan sebagai bukti bahwa siswa mengikuti pembelajaran. Bagi siswa yang tidak mengerjakan tugas dianggap tidak hadir, dan untuk pengumpulan tugasnya dapat dikirim melalui whatsapp atau email sesuai pada waktu yang sudah ditetapkan. Dalam pelaksanaan pembelajaran daring guru harus tetap menggunakan metode pembelajaran. Metode pembelajaran yang dipakai guru PAI berpengaruh terhadap pengetahuan dan pemahaman siswa. Pupuh dan Sobry juga berpendapat yang dikutip oleh (Nasution, 2017) semakin guru menggunakan metode yang tepat dalam mengajar, maka semakin efektif pula dalam mencapai tujuan pembelajaran.

c. Memberikan pengetahuan, pemahaman sehingga siswa dapat mengaplikasikannya

Memberikan pengetahuan dan pemahaman sudah menjadi tugas guru dalam mengajar. Oleh karena itu guru PAI memberikan pengetahuan, pemahaman sehingga siswa dapat mengaplikasikan materi pembelajaran. upaya yang dilakukan guru PAI dalam memberikan pengetahuan, pemahaman sehingga siswa MTs Negeri 3 Bogor dapat mengaplikasikan materi pelajaran tersebut adalah dengan cara: a) menjadikan buku pegangan menjadi acuan siswa b) memintanya untuk membaca dan merangkum materi di buku catatan ataupun menggaris bawahi hal yang penting untuk difahami c) memintanya untuk mencari dan memahami materi dari sumber-sumber yang sudah jelas yang ada di buku, google ataupun youtube, d) siswa menyimak video 
1442 Upaya Guru PAI Dalam Meningkatkan Kemampuan Kognitif Siswa Pada Mata Pelajaran Fiqih Di Masa Pandemi Covid-19 - Nujumul Laily

DOI: https://doi.org/10.31004/edukatif.v3i4.596

pembelajaran yang diberikan oleh guru di group whatsapp e) menjelaskan kembali materi pelajaran fiqih kepada siswa yang belum memahaminya dan f) siswa diminta untuk membuat soal sekaligus langsung menjawabnya, karena jika siswa bisa membuat soal otomatis mereka tau dan faham apa yang mereka pelajari.

Kemampuan kognitif siswa dikatakan baik ketika siswa dapat berpikir dan dapat melakukan 6 tingkatan kognitif seperti pendapat Benyamin S. Bloom dalam buku Psikologi Guru. Konsep dan Aplikasi dari Guru untuk Guru diantaranya meliputi: pengetahuan, pemahaman, aplikasi, analisis, sintesis dan evaluasi (Surya, 2013). Kemampuan kognitif siswa juga dipengaruhi oleh faktor eksternal salah satunya adalah lingkungan sekolah. Lingkungan sekolah merupakan lingkungan dimana siswa belajar atau menuntut ilmu secara sistematis. Keadaan ini meliputi metode belajar, metode mengajar, fasilitas yang mendukung, kurikulum, alat pelajaran, relasi guru dengan siswa, disiplin sekolah dan relasi siswa dengan siswa (Syafi'i et al., 2018).

\section{d. Memberikan Punishment yang mendidik}

Memberikan punishment sangat perlu untuk mendisiplinkan siswa agar tidak melanggar aturan yang sudah ditetapkan. Memberikan punishment bertujuan untuk mendidik siswa di sekolah, tentunya pemberian punishment ini tidak berbentuk ke kerasan, akan tetapi tertuju kepada kedisiplinan. Guru PAI di MTs Negeri 3 Bogor memberikan Punishment kepada siswa yang terlambat dalam mengirimkan tugas dan tidak mengikuti pelajaran tanpa ada keterangan yang jelas. Dikarenakan pembelajaran dilakukan secara daring maka pemberian hukuman ini dilakukan dengan teguran, memberi peringatan dan nasehat yang baik, memberikan tugas tambahan, dan melaporkan hal ini kepada wali kelasnya. Pengumpulan tugas diberi waktu sampai pukul 15.00 WIB. Hal tersebut juga terlihat ketika siswa mengumpulkan tugas melalui whatsapp dengan memfoto hasil tugas yang ia kerjakan. Dengan memberikan punishment kepada siswa akan menjadi acuan pada dirinya sehingga dapat menambah motivasi siswa dalam belajar dan hasil belajar siswa pun meningkat sehingga kemampuan kognitif siswa tinggi. Hal ini didukung oleh penelitian terdahulu bahwa punishment berpengaruh signifikan secara parsial terhadap motivasi belajar siswa (Sujiantari et al., 2016). Hal ini juga sesuai dengan hasil penelitian Umi Kusyairy dan Sulkipli bahwa dengan memberikan reward dan punishment kepada siswa dapat meningkatkan hasil belajar siswa (Kusyairy \& Culo, 2018). Dalam memberikan punishment atau hukuman tidak selalu bersifat negatif yang dapat merugikan siswa serta merusak hubungan antara guru dan siswa, akan tetapi dengan membrikan punishment juga bisa meningkatkan keaktifan serta mengembangkan kreativitas siswa dalam belajar sehingga siswa senang dalam belajar dan suasana atau keadaan belajar dikelas menjadi kondusif (Febianti, 2018).

e. Mengatasi kemampuan kognitif siswa yang rendah

Setiap siswa mempunyai kemampuannya masing-masing, entah dari segi kognitif, afektif dan psikomotorik. Ada siswa yang kemampuan kognitifnya lebih bagus dari pada afektif dan psikomotorik dan juga sebaliknya. Namun guru PAI harus mengatasi kemampuan kognitif siswa yang rendah. Untuk mengatasi kemampuan kognitif siswa yang rendah guru MTs Negeri 3 Bogor memberikan motivasi dan mencari tahu apa yang menyebabkan kemampuan kognitif siswa rendah. Kemudian hal tersebut dikomunikasikan kepada orang tua siswa terkait keterlambatan siswa dalam memahami materi pelajaran tersebut dan meminta bantuan untuk membimbingnya, apalagi untuk kondisi pandemi saat ini proses pembelajaran siswa diambil alih orang tua dirumah maka dari itu harus ada kerja sama antara guru dan orang tua. Motivasi dalam belajar bisa dibedakan jadi 2 jenis yakni intrinsik serta ekstrinsik. Motivasi intrinstik berasal pada diri siswa tersendiri, sebaliknya motivasi ekstrinsik berasal dari luar satu diantaranya ialah guru. Seseorang guru harus bisa meningkatkan serta mengembangkan kedua motivasi tersebut supaya bisa menciptakan kondisi ataupun sesuatu yang memusatkan siswa dalam melaksanakan belajar dengan baik (Ali \& Sobari, 2019). Motivasi yang ada pada diri siswa akan memiliki dampak pada budi pekerti siswa yang berkonsentrasi penuh dalam belajar, ulet, tekun, dan bersemangat. Jika siswa mempunyai motivasi yang tinggi besar kemungkinan siswa akan berhasil dalam belajar sehingga siswa dapat mencapai nilai yang tinggi (Pratama et al., 2019). 
Selain itu guru PAI melakukan pendekatan kepada siswa karena dengan melakukan pendekatan siswa bisa terbuka kepada guru dan guru pun mengetahui kesulitan apa yang dialami siswa pada saat belajar dan guru mengetahui dunia siswa karena guru mempunyai peran penting untuk meningkatkan afektif, kognitif dan psikomotoriknya. Hal ini sesuai dengan hasil penelitian yang dilakukan oleh Elihami dan Abdullah Syahid bahwa dalam melaksanakan pembelajaran perlu adanya pendekatan kepada siswa mulai dari latar belakang siswa, tingkat kecerdasan, motivasi, kondisi dan pengetahuan siswa dalam pembelajaran (Elihami \& Syahid, 2018). Jika dari tindakan diatas belum ada perkembangan terpaksa wali kelas adakan pendekatan kepada siswa dan mengadakan pertemuan dengan orang tua secara langsung karena untuk saat ini orang tua memiliki pengaruh yang sangat besar dalam pembelajaran daring.

Kemudian selanjutnya guru meningkatkan kemampuan kognitif siswa yang rendah pada mata pelajaran fiqih dengan cara guru meminta siswa untuk mencari sumber-sumber di google yang berkaitan dengan materi yang sedang dipelajari, contohnya seperti mencari gambar gerakan wudhu, sholat dan terkait materi yang di praktekan. Hal tersebut dapat menggali daya pikir siswa terkait materi yang dibahas oleh guru. Selain itu guru menaikan standar KKM.

\section{f. Melakukan evaluasi pembelajaran}

Pada point ini harus dilakukan untuk mengukur kemampuan siswa dalam pembelajaran. Evaluasi pembelajaran dilakukan oleh guru PAI setelah selesai membahas semua materi sesuai dengan silabus. Misalnya membahas materi dalam beberapa minggu, kemudian diminggu selanjutnya dilakukan evaluasi seperti pembahasan soal, dan latihan soal yang ada dibuku. Dengan melakukan evaluasi ini guru PAI mengetahui tingkat kemampuan kognitif siswa, dan untuk pengambilan nilai siswa guru mengambilnya dari kehadiran, ulangan harian, penilaian praktek, UTS, UAS dan pengumpulan tugas. Evaluasi pembelajaran juga dilakukan dengan menggunakan sistem aplikasi karena memudahkan guru dan siswa pada masa pandemi saat ini. Jika nilai siswa dibawah KKM maka siswa tersebut harus mengikuti remedial untuk mencapai KKM tersebut. Hal ini sesuai dengan hasil penelitian terdahulu yang dilakukan oleh Andi Fitriani Djollong dan Anwar Akbar bahwa penilaian yang dilakukan guru PAI kepada siswa di salah satu sekolah SMP PGRI meliputi kegiatan kognitif yang biasanya dilaksanakan untuk mendapatkan nilai ulangan harian, UTS dan UAS dan juga penilaian keterampilan atau psikomotorik siswa dengan praktek ibadah sekaligus sikap atau afektif siswa dengan menggunakan jurnal (Djollong \& Akbar, 2019).

Evaluasi ialah satu diantara beberapa komponen penting serta tahapan yang wajib dicapai untuk mengetahui seberapa efektif dan efisien proses pembelajaran. Evaluasi pembelajaran merupakan suatu tahapan terakhir dari proses pembelajaran dikelas. Dengan melakukan evaluasi dapat diketahui keberhasilan dari proses pembelajaran sesuai dengan tujuan yang diharapkan. Evaluasi meliputi semua aspek pembelajaran, baik aspek kemampuan kognitif, afektif dan psikomotorik (Ismail, 2020). Berdasarkan observasi, sekolah MTs Negeri 3 Bogor melakukan evaluasi pembelajaran dengan mengikuti ketentuan pemerintah, siswa melaksanakan UTS secara daring dengan mengisi soal melalui google Form yang disediakan oleh pihak sekolah. Penilaian yang dilakukan guru PAI di MTs Negeri 3 Bogor dilakukan tidak hanya dari mengisi soal UTS/UAS akan tetapi penilaian dilakukan dari segi afektif, kognitif dan psikomotorik siswa.

\section{Faktor yang Mempengaruhi Kemampuan Kognitif Siswa}

Tentunya ada banyak faktor yang mempengaruhi kemampuan kognitif siswa di MTs Negeri 3 Bogor, entah dari dirinya sendiri, orang tua atau lingkungannya. Namun untuk saat ini yang mempengaruhi kemampuan kognitif siswa di MTs Negeri 3 Bogor adalah media social. Media social mempengaruhi kemampuan kognitif siswa baik dari segi positif atau negatif, dari segi positif media sosial digunakan siswa untuk pembelajaran daring sehingga memudahkan guru dan siswa dalam melakukan proses pembelajaran dan untuk dari segi negatifnya siswa banyak menggunakan waktu dengan media sosial seperti game dan lain sebagainya. Berdasarkan wawancara dengan siswa bahwa kemampuan kognitif siswa MTs Negeri 3 Bogor dipengaruhi oleh berbagai macam faktor, yaitu faktor internal dan eksternal. Faktor internal yang 
1444 Upaya Guru PAI Dalam Meningkatkan Kemampuan Kognitif Siswa Pada Mata Pelajaran Fiqih Di Masa Pandemi Covid-19 - Nujumul Laily

DOI: https://doi.org/10.31004/edukatif.v3i4.596

mempengaruhi kemampuan kognitif siswa MTs Negeri 3 Bogor adalah dirinya sendiri, karena jika siswa rajin dalam belajar maka kognitifnya pun akan baik, begitu juga sebaliknya. Sedangkan faktor eksternal yang mempengaruhi kemampuan kognitif siswa ialah orang tua, sekolah dan lingkungan.

Orang tua memiliki pengaruh terhadap kognitif siswa, entah dari latar belakang pendidikan orang tua, cara membimbing anaknya, memberikan motivasi atau dukungan kepada anakny dan lain sebagainya. Sekolah juga menjadi pengaruh dalam kognitif siswa, bagaimana kompetensi yang dimiliki guru, bagaimana cara guru memberikan materi pelajaran, cara guru mengkondisikan kelas yang saat ini melalui virtual, cara guru mengajar dan masih banyak lagi. Selanjutnya yang mempengaruhi kemampuan kognitif siswa dari segi lingkungan baik itu teman bergaul atau masyarakat. Jika lingkungannya baik maka akan berdampak baik juga kepada siswa dan juga sebaliknya.

Di masa pandemi ini terjadi beberapa problem dan kendala yang di alami oleh siswa MTs Negeri 3 Bogor dalam mengikuti pembelajaran daring. Satu diataranya adalah siswa sulit untuk menerima pembelajaran. Ini disebabkan waktu pembelajaran yang singkat, kurang nya penjelasan dari guru dan terkendala dari segi sinyal dan kuota. Sebagaimana penelitian yang dilakukan oleh Firmansyah bahwa kendala dalam melaksanakan pembelajaran daring dapat terjadi dikarenakan kurangnya persiapan dari beberapa pihak yang terlibat pada sistem pembelajaran daring. Diantaranya kesediaan kuota, latar belakang siswa yang bermacam-macam dalam pelaksanaan pembelajaran daring, kekuatan sinyal dan kemampuan siswa dalam menggunakan IT yang berbeda-beda. Selain itu guru juga kurang dalam mendesain model pembelajaran daring yang tepat sehingga siswa kurang termotivasi dalam belajar (Firmansyah, 2021).

\section{KESIMPULAN}

Dari hasil penelitian diatas dapat disimpulkan bahwasanya upaya yang dilakukan guru PAI dalam meningkatkan kemampuan kognitif siswa di masa pandemi Covid-19 yaitu meliputi: menggunakan media pembelajaran whatsapp, menggunakan metode pembelajaran penugasan, memberikan pengetahuan, pemahaman sehingga siswa dapat mengaplikasikannya, memberikan punishment yang mendidik, mengatasi kemampuan kognitif siswa yang rendah dan melakukan evaluasi pembelajaran. Dan faktor yang mempengaruhi kemampuan kognitif siswa adalah faktor internal dan eksteral yakni pada dirinya sendiri, orang tua, guru, teman serta lingkungannya dan juga terdapat beberapa kendala dalam melakukan pembelajaran diantaranya waktu yang singkat, penjelasan guru yang singkat, terbatasnya sinyal dan kuota.

\section{DAFTAR PUSTAKA}

Ali, H., \& Sobari, A. (2019). Hubungan Motivasi Berprestasi Terhadap Kedisiplinan Siswa Di Smps It Roudlotul Jannah Kabupaten Bogor. E-Jurnal Mitra Pendidikan, 3(7), 1057-1068.

Daheri, M., Juliana, J., Deriwanto, D., \& Amda, A. D. (2020). Efektifitas whatsapp sebagai media belajar daring. Jurnal Basicedu, 4(4), 775-783.

Djollong, A. F., \& Akbar, A. (2019). Peran Guru Pendidikan Agama Islam Dalam Penanaman Nilai-Nilai Toleransi Antar Ummat Beragama Peserta Didik Untuk Mewujudkan Kerukunan. Al-'Ibrah: Jurnal Pemikiran Dan Pendidikan Islam, 8(1), 72-92.

https://www.umpar.ac.id/jurnal/index.php/ibrah/article/view/22

Elihami, E., \& Syahid, A. (2018). Penerapan Pembelajaran Pendidikan Agama Islam Dalam Membentuk Karakter Pribadi Yang Islami. Edumaspul - Jurnal Pendidikan, 2(1), 79-96. https://doi.org/10.33487/edumaspul.v2i1.17

Febianti, Y. N. (2018). Jurnal Edunomic Vol. 6, No. 2, Tahun 2018 93. Jurnal Edunomic, 6(2), 93-102. https://core.ac.uk/download/pdf/229997374.pdf

Firmansyah, F. (2021). Motivasi Belajar dan Respon Siswa terhadap Online Learning sebagai Strategi Pembelajaran di Masa Pandemi Covid-19. Edukatif: Jurnal Ilmu Pendidikan, 3(2), 589-597. 
1445 Upaya Guru PAI Dalam Meningkatkan Kemampuan Kognitif Siswa Pada Mata Pelajaran Fiqih Di Masa Pandemi Covid-19 - Nujumul Laily

DOI: https://doi.org/10.31004/edukatif.v3i4.596

Handarini, O. I., \& Wulandari, S. S. (2020). Pembelajaran Daring Sebagai Upaya Study From Home (SFH) Selama Pandemi Covid 19. Jurnal Pendidikan Administrasi Perkantoran (JPAP), 8(3), 496-503.

Indonesia, P. R. (2006). Peraturan pemerintah Republik Indonesia Nomor 19 tahun 2005 tentang standar nasional pendidikan. Jakarta.

Ismail, M. I. (2020). Evaluasi Pembelajaran (P. Vita (ed.); 1. Cet. 1). Rajawali Pers.

Kusyairy, U., \& Culo, S. (2018). Meningkatkan Hasil Belajar Peserta Didik Melalui Pemberian Reward And Punishment. Jurnal Pendidikan Fisika, 6(2), 81-88.

Nasution, M. K. (2017). Penggunaan metode pembelajaran dalam peningkatan hasil belajar siswa. Studia Didaktika: Jurnal Ilmiah Bidang Pendidikan, 11(1), 9-16.

Parameswara, M. C., \& Dewi, D. A. (2021). Efektivitas Penggunaan Metode Latihan dan Penugasan dalam Pembelajaran Daring di Masa Pandemi pada Mata Pelajaran PKN di Sekolah Dasar. Jurnal Pendidikan Tambusai, 5(1), 874-883.

Prasetyo, T., \& Zulela, M. S. (2021). Proses Pembelajaran Daring Guru Menggunakan Aplikasi Whatsapp Selama Pandemik Covid-19. Jurnal Elementaria Edukasia, 4(1).

Pratama, F., Firman, \& Neviyarni. (2019). Pengaruh Motivasi Belajar IPA Siswa Terhadap Hasil Belajar. Edukatif: Jurnal Ilmu Pendidikan, 1(3), 280-286. https://edukatif.org/index.php/edukatif/index\%0APENGARUH

Pritandhari, M. (2017). Jurnal Promosi Jurnal Pendidikan Ekonomi UM Metro | 64. 5(1), 1-7.

Pustikayasa, I. M. (2019). Grup WhatsApp Sebagai Media Pembelajaran. Widya Genitri: Jurnal Ilmiah Pendidikan, Agama Dan Kebudayaan Hindu, 10(2), 53-62. https://doi.org/10.36417/widyagenitri.v10i2.281

RI, M. K. dan P. (2020). Surat Edaran Nomor 4 Tahun 2020 tentang Pelaksanaan Kebijakan Pendidikan dalam Masa Darurat Penyebaran Coronavirus Disease (COVID-19).

Rozana, S. dkk. (2020). Pengembangan Kognitif Anak Usia Dini Teori dan Praktik. (R. S. Dewi (ed.); cet. 1). Edu Publisher.

Rumondor, P., \& Nailil, M. (2019). Upaya Guru PAI dalam Meningkatkan Kompetensi Kognitif dan Kepribadian Siswa Di MTs Negeri 1 Bongkudai. Edureliga: Jurnal Pendidikan Agama Islam, 3(1), 41 58. https://doi.org/10.33650/edureligia.v3i1.903

Sujiantari, N. K., Sujana, I. N., \& Zukhri, A. (2016). Pengaruh Reward dan Punishment terhadap Motivasi Belajar Siswa dalam Pembelajaran IPS (Studi Pada SMP Negeri 1 Singaraja Kelas VIII Tahun Ajaran 2015/2016). Jurnal Pendidikan Ekonomi Undiksha, 7(2).

Surya, M. (2013). Psikologi Guru Konsep dan Aplikasi dari Guru untuk Guru (A. \& D. N. Hasim (ed.); Cet. 1). Alfabeta.

Syafi'i, A., Marfiyanto, T., \& Rodiyah, S. K. (2018). Studi Tentang Prestasi Belajar Siswa Dalam Berbagai Aspek Dan Faktor Yang Mempengaruhi. Jurnal Komunikasi Pendidikan, 2(2), 115. https://doi.org/10.32585/jkp.v2i2.114

Syarifudin, A. S. (2020). Impelementasi Pembelajaran Daring Untuk Meningkatkan Mutu Pendidikan Sebagai Dampak Diterapkannya Social Distancing. Jurnal Pendidikan Bahasa Dan Sastra Indonesia Metalingua, 5(1), 31-34. https://doi.org/10.21107/metalingua.v5i1.7072 